pp. $407-421$

\title{
The Exploring of Trust that Influences Customer's Intention to Use FinnTech M-Banking Application on Regional Banks
}

Submitted 18/06/20, $1^{\text {st }}$ revision 12/07/20, $2^{\text {nd }}$ revision 30/08/20, accepted 10/09/20

\author{
Gede Cahyadi Putra ${ }^{1}$, Ni Putu Yeni Astiti ${ }^{2}$, \\ Gusti Ngurah Bagus Gunadi ${ }^{3}$
}

\begin{abstract}
:
Purpose: Information technology is growing rapidly in Indonesia, bringing drastic changes in the lifestyle of the Indonesian people, especially in Bali. Digital technology has increased ease of use, efficiency, and savings in every activity. The Financial Technology System is an online financial payment that is usually provided by banks. This study aims to analyze trust as an intervening variable in relation to ease of use, perceived usefulness, and perceived value of customers' intended use of M-Banking financial services.
\end{abstract}

Approach/Methodology/Design: Data collection was carried out by distributing questionnaires, where the population is the BPD Mobile Banking system customers in Bali, Indonesia. This is a descriptive and verification research, a descriptive method based on assessment analysis and a verification method based on quantitative analysis. The samples were determined by purposive sampling and the analysis technique used the Partial Least Square (PLS).

Findings: The results showed that perceived ease of use, perceived usefulness and perceived value had a positive and significant effect on intention to use the mobile banking system, perceptions of application usability had the most significant effect on intention to use compared to perceived convenience and perceived value of the mobile banking system.

Practical Implications: The results show that although the BPD Mobile banking system has provided several benefits for customers, it is still not actively used by customers compared to other bank mobile banking systems in Indonesia.

Originality/Value: The article emphasizes the usefulness of customers so that trust is created and will reuse the M-banking facility provided by the bank to facilitate consumer financial transactions.

Keywords: Perceived ease of use, perceived usefulness, perceived value, trust, intention to use, M-banking, FinnTech.

JEL classification: 615, G32.

Paper Type: Literature review study.

\footnotetext{
${ }^{1}$ Faculty of Economic and Business, Mahasaraswati Denpasar University, Bali, Indonesia; E-mail: gdcahyadi@unmas.ac.id

${ }^{2}$ Faculty of Economic and Business, Mahasaraswati Denpasar University, Bali, Indonesia; E-mail: yeni.astiti@unmas.ac.id

${ }^{3}$ Faculty of Economic and Business, Mahasaraswati Denpasar University, Bali, Indonesia; E-mail: gunadi@unmas.ac.id
} 


\section{Introduction}

Technology, in both developed and developing countries continues to change. The development and innovation of information technology in Indonesia as a developing country has brought major changes to various sectors of human life. The development of information technology at this time has experienced drastic and exciting progress and has helped encourage the lifestyle of the Indonesian people towards information technology. All sectors were affected including social, cultural, defense, financial and education as well as the payment system. One of the significant changes is Financial Technology or commonly referred to as fintech. Financial Technology is a phenomenon that combines information technology and financial systems into different business models. Financial Technology benefits society in terms of payment system services, including instruments, administrators, mechanisms, and the infrastructure to conduct payment transaction processing faster, easier, and safer.

All companies need to develop the ability to apply innovation in developing products and processes so that they are different from competitors in providing products and services to consumers (Setini et al., 2020). Consumers can distinguish and choose between products and services that provide different capabilities and advantages so that their intention to use Ravichandran et al. (2016).

The high advancement of data innovation has been considered dependent on the enormous development of web clients. These advancements are to cook for the interest of fast administrations, productive cycle and to spare cost contrast with the traditional and tedious cycle.

Figure 1. The Growth of Internet User Asia and Indonesia
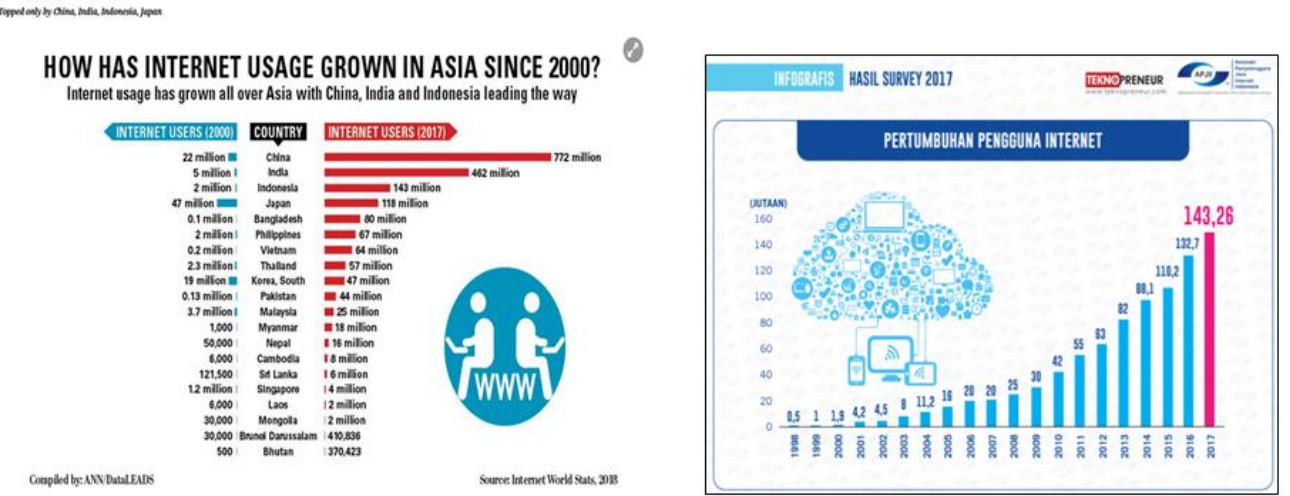

Source: $w w w . t h e d a i l y s t a r . n e t$

Based on the results of data from the daily star (www.thedailystar.net) from 2000, the development of technology use continues to experience very rapid developments. A survey released by APJII conducted in 2017, the penetration of internet users by 
city/district was concentrated in urban areas with a percentage of $73 \%$, rural urban areas $(50 \%)$, and rural areas (48\%). This high penetration is due to the availability of fiber optic joints and other supporting infrastructure that supports internet activity. The results of this survey relate to the penetration of total internet users in Indonesia, which grew almost 8 percent to 143.26 million people or $55 \%$ of the total population of 300 million people in Indonesia.

Figure 2. The Economy of Internet Use

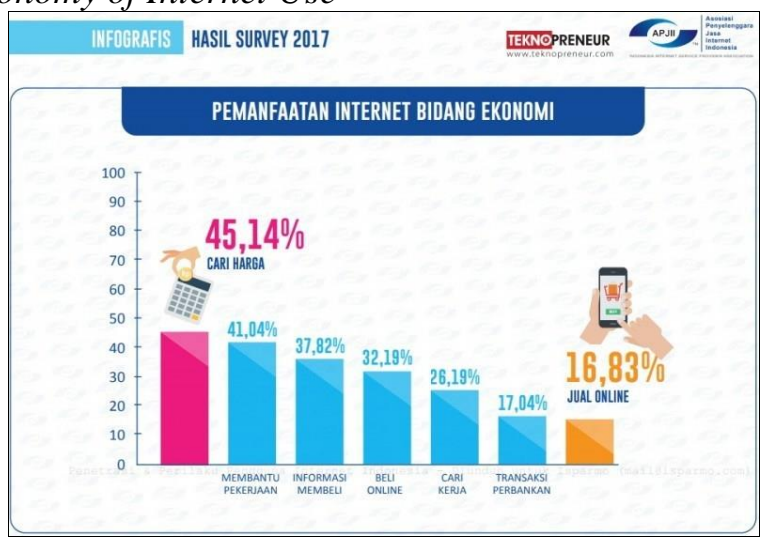

Source: Indonesian Internet Service Providers Association (APJII)

According to the above-mentioned data collected in 2017 that out of 144 million internet users in the survey done in Indonesia, there are only $18 \%$ internet users who use the internet to access their banking transaction services. This figure includes all mobile banking services provided by all the banks in Indonesia, mobile banking is the service that uses internet media as the intermediary services. Versatile banking is the financial help application that plans to encourage client for simple exchanges without coming in and do exchange over the counter where at times need to line for the financial administrations. Client gripes for the long line and tedious to get banking administrations. Subsequently, with the versatile financial application client can do their bank exchanges and administrations over web whenever anyplace without going to the bank.

The administrations gave by versatile banking are including money related exchanges, non-budgetary exchanges, finance moves, balance checking and charge installments. Clients can likewise utilize this versatile financial application open and close a financial record without coming down to the bank. These administrations can be handled from the client's cell phone after they have introduced the versatile financial application. All these financial administrations can be applied by the clients at whatever point their cell phone can be associated with the web.

Practically the entirety of the banks in Indonesia are contending to give portable financial administrations to help the powerful and usability of banking exchanges, this administration is to focus on the adequacy and effectiveness of clients directing 
their different exchanges online through their cell phone. Portable financial administrations is relied upon to decrease the difficulty of manual cycle and offer common sense to clients so as to play out their financial exchanges without need to line at bank over the counters that are tedious and wasteful.

Table 1. Top Brand Award Mobile Banking

\begin{tabular}{|l|l|l|l|}
\hline No. & Bank & TBI & TOP \\
\hline 1. & BCA m-banking & $44,5 \%$ & TOP \\
\hline 2. & BRI Mobile & $17,0 \%$ & TOP \\
\hline 3. & Mandiri m-Banking & $16,6 \%$ & TOP \\
\hline 4. & BNI Mobile & $12,3 \%$ & \\
\hline 5. & CIMB Niaga Mobile & $3,4 \%$ & \\
\hline
\end{tabular}

Source: Topbrand-award-2019.com

Table 1 above is explaining the data of bank's mobile banking service providers which were ranked among the top 5 best mobile banking preferred by customer on 2019 survey according to the Top Brand Award. The users of BCA mobile banking service have around 10 million downloaders on the Google Play-store and App Store application, thus BCA mobile banking has won the top ranking brand award in the echannel category with the percentage of $44.5 \%$, and followed by BRI mobile banking as the second top brand ranking with the percentage of $17.0 \%$ and in the third rank is Mandiri mobile banking with the percentage of $16.6 \%$.

Among all the banks, one of them that also provide mobile banking services is Bank BPD Bali. To compete and provide better services to the customer, Bank BPD provide their mobile banking services called BPD Mobile. BPD Mobile is an electronic banking service provided for customers to access their accounts and conduct all banking transactions by sending transaction instructions through their mobile phone. (www.bpdbali.co.id). BPD mobile is not classified as one of the top brands and based on a preliminary survey conducted on 30 BPD Bank customers, as respondents indicated that there are several shortcomings of the BPD Mobile system which is a regional bank that eventually made them leave this service. The purpose of this research is to find out why customers leave this BPD Mobile banking service.

\subsection{Research Gap}

Based on several discussions from the previous researches, where according to Gitahi and Misango (2020), Lutfi et al. (2020), Ravichandran et al. (2016) explained that commercial banks should demonstrate benefits to customers that many of the benefits are provided by adopting and using mobile banking rather than using conservative banking methods. Al-Dmour (2020), Ouma and Ndede (2020) explained that the results of the study concluded that the volume of mobile banking transactions had a positive influence on the financial performance of Jordan Bank and Kenya Bank (Tam and Oliveira, 2017). Many studies found on the interest using banking technology but very rarely have examined how the adoption after use, the 
perception of ease and usefulness is a significant way of adopting M-banking. Puriwat and Tripopsakul (2017) uncovered that banks must accentuate procedures to improve the view of the apparent convenience of versatile banking by thinking about these variables. This investigation is likewise one of the first to look at the joined TAM and MSQ model with regards to m-banking appropriation. Del Mundo (2019) looks at the absence of offices in computerized banking, to be specific little banks actually utilize advanced banking as a choice to draw in clients, the first page show is excessively befuddling, frequently unsteady, and security is not ensured. Maseke (2018), Khosa (2019) clarified that banks ought to have the option to improve versatile financial administrations that can give customers to discover what their desires are and whether they will be happy with the administrations given by banks.

Johannes et al. (2018), Dong et al. (2019) clarified that the examination led had a positive impact between convenience, consumer loyalty, client support and trust in the steadfastness of the utilization of versatile banking. Aldiabat et al. (2019) affirmed that finding that the Access Supportive factor of portable banking is powerful on client fulfillment identified with versatile banking. Some of the results of previous studies show more about the mobile banking application where most of the researchers study more theoretically which shows a research gap.

The authors in this study will strive more empirically based on field observations and methodological studies based on the variables built, namely perceived usefulness, perceived ease of use, perceived value, trustworthiness and intention to use, where in general the research is explained theoretically which are the research gaps that can be found, so that the authors feel the need to conduct research and studies empirically through the methodology of interest in using mobile banking applications, be it the perception of ease of use, perceived usefulness or perceived value and system trust that affects customer intention to use the mobile banking application on Regional bank in Bali.

\section{Literature Review}

\subsection{Perceived Usefulness M-banking}

Shiau et al. (2020) explained that apparent convenience is something that states people accept the utilization of a specific innovation will improve the exhibition of people. Seen convenience is the view of helpfulness characterized as a measure where the utilization of an innovation is accepted to carry handiness to the individuals who use it. According to Kotler and Armstrong (2016) a solid type of division is to assemble purchaser's dependent on the distinctive handiness they look for from an item. The principle helpfulness looked for by customers in the item class, the sort of shoppers who search for each advantage, and the fundamental brands that give each advantage. 


\subsection{Perceived Ease of Use M-banking}

Zheng et al. (2019) explain in their research that perceived ease of use is the level or circumstance where somebody accepts that utilizing a specific framework does not need any exertion (liberated from exertion). The intensity of use and interaction between users and the system can also indicate ease of use. Perceived ease of use can be measured by the following indicators: easy to learn, easy for users, and easy to operate. Perceived ease of use is defined as the level of trust of individuals who use new technology will be free from difficulties (Davis, 1989). This has a strong influence on behavioral intentions on information technology adoption. If a technology is perceived as easy to use, people will choose to implement it. The application of ease of use in the context of research is that customers believe through the internet will be flexible in making use of, easy in learning the use of applications.

\subsection{Perceived Value M-banking}

Kotler and Keller (2016) assert that perceived value is making up of a host of inputs, such as the buyer's image of the product performance, the channel deliverables, the warranty quality, customer support and softer attributes such as the supplier's reputation, trustworthiness and esteem. Wang et al. (2019) express that perceived value is the value perceived by the customer who is different between the customer's assessment of all the benefits and costs of an offer against its alternatives. Companies must deliver the value promised by their value proposition, and the customer must perceive the value.

\subsection{Trust M-banking}

Setini et al (2020), Putra et al. (2020) explain that trust is the taste or what consumers think of the actions of other parties during a certain process, with the hope that other parties will adopt acceptable practices and be able to provide the products and services they have promised. According to Kotler and Armstrong (2016), Sapta et al. (2020) trust is a descriptive thought that someone has about something. Trust may be based on real knowledge, opinions, or faith and may or may not bring about emotional. Marketers will be interested in the trust that people formulate about certain products and services because this trust shape the image of products and brands that influence consumer buying behavior.

\subsection{Intention to Use M-banking}

Shields et al. (2020) explained that interest in using is intention, generally defined as a deep desire to do something that is preferred. An individual who knows information about an online site can make him interested to do something related to which causes a sense of interest. According to Kotler and Armstrong (2016) consumers can form purchase and use interests based on factors such as expected income, expected prices, and expected product benefits. However, unexpected 
events can change your purchase and usage interests. As such, preferences and even interest in buying and using do not always result in actual purchasing and usage choices (Thalassinos and Thalassinos, 2018).

\subsection{Relationship between Variables and Hypothesis}

Zheng et al. (2020) explained that perceived usefulness is something that states individuals believe that the use of a particular technology will improve the performance of individuals. Zheng et al. (2019) explain in their research that perceived ease of use is the level or situation where someone believes that using a particular system does not require any effort (free of effort). Setini et al. (2020) explain that Trust is "the willingness of consumers that depend on other parties and be vulnerable to other parties' actions during a certain process, with the hope that the other party will adopt acceptable practices and will be able to provide the products and services that they have promised". Wang et al. (2019) express that perceived value is the value perceived by the customer who is different between the customer's assessment of all the benefits and costs of an offer against its alternatives. Therefore, the research hypotheses are formed as follows:

$H_{1}$ : The influence of perceived usefulness M-banking towards trust M-banking.

H2: The influence of perceived ease of use M-banking towards trust M-banking.

$H_{3}$ : The influence of perceived value M-banking towards trust M-banking.

$H_{4}$ : The influence of perceived ease of use M-banking towards intention to use M-banking.

$H_{5}$ : The influence of perceived usefulness M-banking towards intention to use M-banking.

$H_{6}$ : The influence of perceived value M-banking towards intention to use Mbanking.

$H_{7}$ : The influence of trust M-banking towards intention to use M-banking.

Figure 3. Research Framework

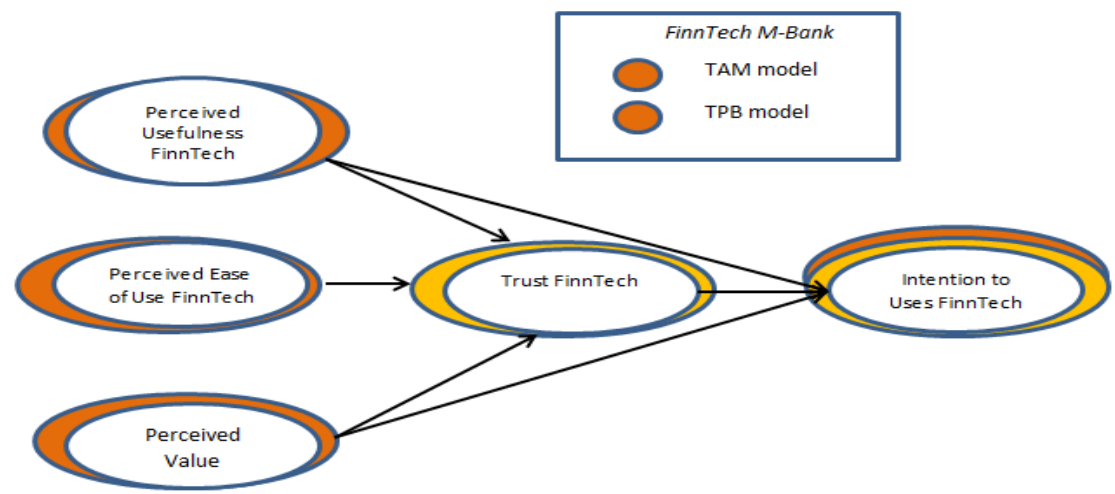

Source: Own study. 


\section{Research Methodology}

The research designed in this study uses descriptive and verification methods with the type of causal investigation of the relationship and influence between exogenous and endogenous variables. The analysis design carried out in testing the research hypothesis is to conduct a study of the BPD Mobile banking application customers in Bali. This research begins with a pre-survey study of 30 customers as respondents and is continued by formulating the research variable constructs. The observation process in this study uses a time horizon with a cross section, collective data is obtained through research conducted in 2020, the unit of analysis is the BPD Mobile banking application located in Bali. The observation unit is a customer who uses the BPD Mobile banking application located around Bali. The analysis design used SEM-PLS. Validity testing is done by using a random sample of 300 respondents to BPD Mobile banking application customers. will indicate the variance of items with either correct or incorrect format such as Likert scale format. The Cronbach's Alpha coefficient is mostly used to evaluate internal consistency.

\section{Results and Discussion}

\subsection{Results}

The results of descriptive analysis conducted on the customer of BPD Mobile banking application to find out the intention to use the mobile banking application based on the perceived ease of use, the perceived usefulness and perceived value of the mobile banking application. Based on the above-mentioned independent variable and then to find out the most significant influence of the variables towards the dependent variable of intention to use of the customers against the mobile banking application. The measurement model of analysis above showed the link between manifest variables (indicators) and each of the latent variables. The analysis of the measurement model is to test the validity and reliability of each of the dimensions and the indicators utilized to measure the variables constructed earlier. The analysis of the measurement model will describe the value of discriminant validity by looking at the value of square root of Average Variance Extracted (AVE) with the suggestion value above 0,5, loading factor $(>0.5)$, and constructed Composite Validity and Reliability (Cronbach's Alpha >0.70), are concluded that the dimensions and indicators are classified as reliable (Table 2).

The value of $\mathrm{R}^{2}$ shows that the criterion is strong, with large $\mathrm{Q}$ value, this figure conclude that the propose model are supported by the empirical research classified as fit. Similarly, the value of AVE is $>0.5$, which indicate that all variables in the model are estimated to meet the cirteria of discriminant validity. The value of both Composite Reliability and Cronbach's Alpha for each of the variables are $>0.70$, which means that all the researched variables are classified as reliable and the outer model of this research is also classified as fit. 
Table 2. Goodness of Fit Model (GoF)

\begin{tabular}{|l|l|l|l|l|l|}
\hline Variable & AVE & $\begin{array}{l}\text { Composite } \\
\text { Reliability }\end{array}$ & $\begin{array}{l}\text { Cronbach's } \\
\text { Alpha }\end{array}$ & $\begin{array}{l}\text { R } \\
\text { Square }\end{array}$ & $\begin{array}{l}\text { Q } \\
\text { Square }\end{array}$ \\
\hline Perceived Usefulness & 0.660 & 0.947 & 0.930 & - & 0.564 \\
\hline Perceived Ease of Use & 0.686 & 0.934 & 0.942 & - & 0.667 \\
\hline Perceived Value & 0.747 & 0.917 & 0.891 & - & 0.451 \\
\hline Trust & 0.625 & 0.947 & 0.928 & 0.543 & 0.477 \\
\hline Intention to Use & 0.728 & 0.954 & 0.953 & 0.595 & 0.226 \\
\hline
\end{tabular}

Source: From Data Processing FinnTech m-Banking BPD(2020).

The result of measurement based on the data processing of model analysis on the dimensions indicates that the overall indicators which were processed above are classified as valid, as most of the value from the loading factors are greater than 0.70 . Table 3 below presents the results of the measurement model analysis of each latent variable against the dimensions.

Table 3. Loading Factor Between Latent Variables and Dimensions

\begin{tabular}{|l|l|l|l|}
\hline Latent Variables-Dimensions & $\begin{array}{l}\text { Loading } \\
\text { factor } \\
(\lambda)\end{array}$ & $\begin{array}{l}\text { Standard } \\
\text { Error } \\
(\mathbf{S E})\end{array}$ & $\begin{array}{l}\mathbf{T} \\
\text { Statistics } \\
(\mid \lambda / \text { SE } \mid)\end{array}$ \\
\hline Perceived Usefulness $\rightarrow$ Ease & 0.850 & 0.043 & 17.596 \\
\hline Perceived Usefulness $\rightarrow$ Advantege & 0.851 & 0.086 & 20.428 \\
\hline Perceived Usefulness $\rightarrow$ Allocate & 0.746 & 0.023 & 21.682 \\
\hline Perceived Ease of Use $\rightarrow$ Easy to Learn & 0.826 & 0.064 & 12.824 \\
\hline Perceived Ease of Use $\rightarrow$ Easy to Use & 0.754 & 0.013 & 15.651 \\
\hline Perceived Ease of Use $\rightarrow$ Easy to Operate & 0.861 & 0.043 & 18.743 \\
\hline Perceived Value $\rightarrow$ Performance & 0.848 & 0.054 & 19.539 \\
\hline Perceived Value $\rightarrow$ Deliverables & 0.831 & 0.026 & 18.749 \\
\hline Perceived Value $\rightarrow$ Quality & 0.812 & 0.080 & 19.848 \\
\hline Trust $\rightarrow$ Integrity & 0.719 & 0.056 & 24.539 \\
\hline Trust $\rightarrow$ Honesty & 0.819 & 0.038 & 22.740 \\
\hline Trust $\rightarrow$ Goodness & 0.852 & 0.082 & 22.462 \\
\hline Intention to Use $\rightarrow$ Expected Benefits & 0.781 & 0.089 & 17.659 \\
\hline Intention to Use $\rightarrow$ Expected Usability & 0.810 & 0.049 & 25.639 \\
\hline Intention to Use $\rightarrow$ Expected Profit & 0.867 & 0.048 & 15.736 \\
\hline
\end{tabular}

Source: From Data Processing FinnTech m-Banking BPD (2020).

The estimated value for the path analysis in the structural model must be significant. This significant value can be obtained by the bootstrapping procedure. The significance of the hypothesis is by looking at the value of the parameter coefficient and the significance value of the T-statistics on the bootstrapping algorithm report. To find out the significant or insignificant is seen from the T-table at alpha 0.05 $(5 \%)=1.96$. Then, T-tables are to compare with the T-counts (T-statistics) as explained in Table 4. From the results of hypothesis testing, it was revealed that perceived usefulness has the highest influence on intention to use compared to perceived ease of use and perceived value. The direct effect of perceived value has the highest influence against intention to use rather than perceived ease of use and perceived usefulness. Trust is also an important factor in determining the effect of 
The Exploring of Trust that Influences Customer's Intention to Use FinnTech M-Banking Application on Regional Banks

intention to use the mobile banking application (Figure 4). Testing results are presented in Figure 5.

Table 4. The Results of Hypothesis Testing

\begin{tabular}{|l|l|l|l|l|l|}
\hline & $\begin{array}{l}\text { Original } \\
\text { Sample } \\
(\mathrm{O})\end{array}$ & $\begin{array}{l}\text { Sample } \\
\text { Mean } \\
(\mathrm{M})\end{array}$ & $\begin{array}{l}\text { Standard } \\
\text { Deviation } \\
(\mathrm{STDEV})\end{array}$ & $\begin{array}{l}\mathrm{T} \text { Statistics } \\
(|\mathrm{O} / \mathrm{STDEV}|)\end{array}$ & P Values \\
\hline $\begin{array}{l}\text { Perceived Usefulness } \rightarrow \\
\text { Trust }\end{array}$ & 0.346 & 0.369 & 0.184 & 5.428 & 0.035 \\
\hline $\begin{array}{l}\text { Perceived Ease of Use } \rightarrow \\
\text { Trust }\end{array}$ & 0.319 & 0.338 & 0.179 & 4.681 & 0.012 \\
\hline Perceived Value $\rightarrow$ Trust & 0.152 & 0.263 & 0.179 & 4.253 & 0.045 \\
\hline $\begin{array}{l}\text { Perceived Ease of Use } \rightarrow \\
\text { Intention to Use }\end{array}$ & 0.330 & 0.331 & 0.156 & 2.129 & 0.021 \\
\hline $\begin{array}{l}\text { Perceived Usefulness } \rightarrow \\
\text { Intention to Use }\end{array}$ & 0.236 & 0.034 & 0.163 & 2.844 & 0.000 \\
\hline $\begin{array}{l}\text { Perceived Value } \rightarrow \text { Intention } \\
\text { to Use }\end{array}$ & 0.265 & 0.258 & 0.065 & 3.983 & 0.000 \\
\hline Trust $\rightarrow$ Intention to Use & 0.018 & 0.023 & 0.051 & 7.347 & 0.023 \\
\hline
\end{tabular}

Source: From Data Processing FinnTech m-Banking BPD (2020).

Figure 4. Hypothesis Testing

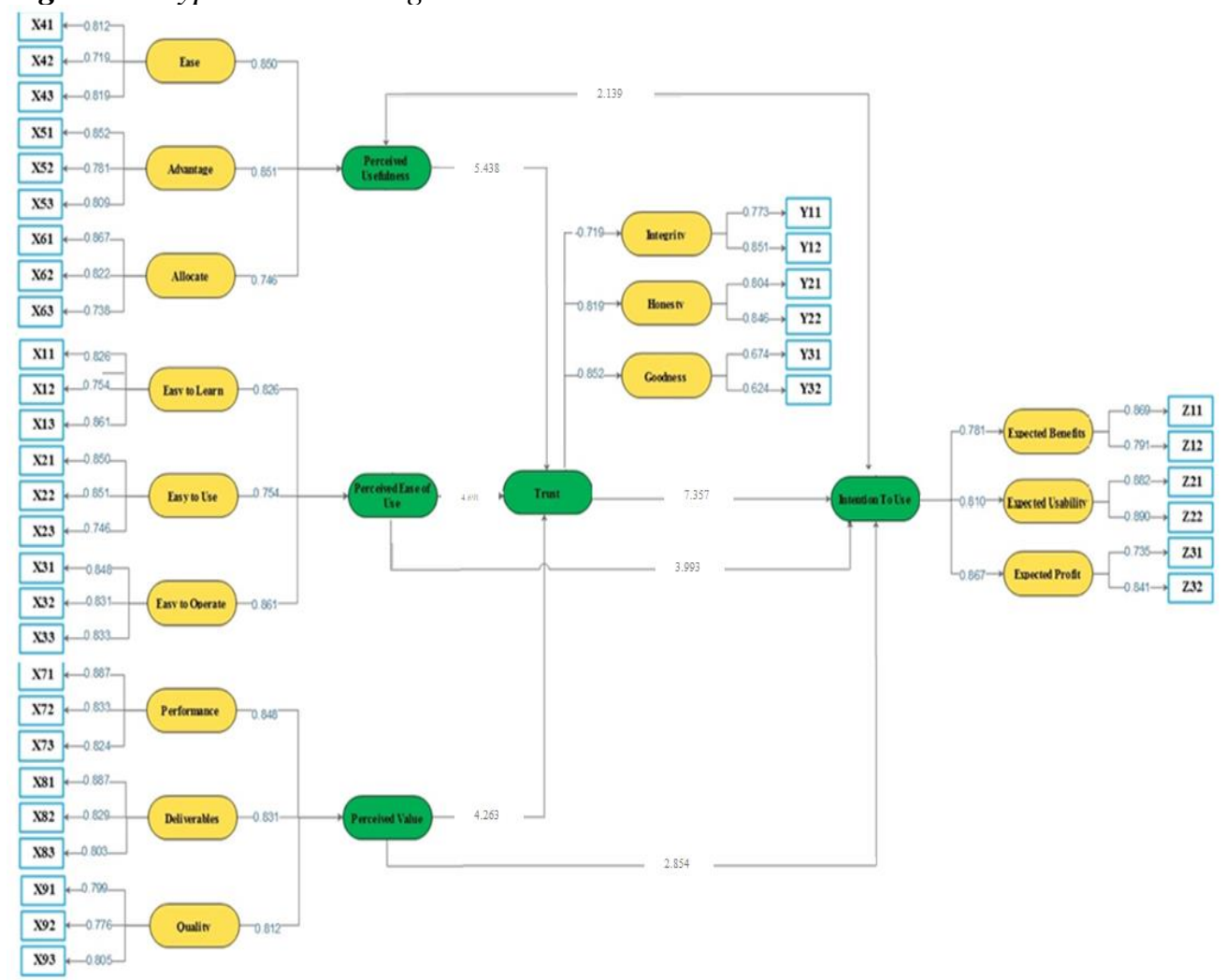

Source: From Data Processing FinnTech m-Banking BPD (2020). 
Figure 5. Testing Results

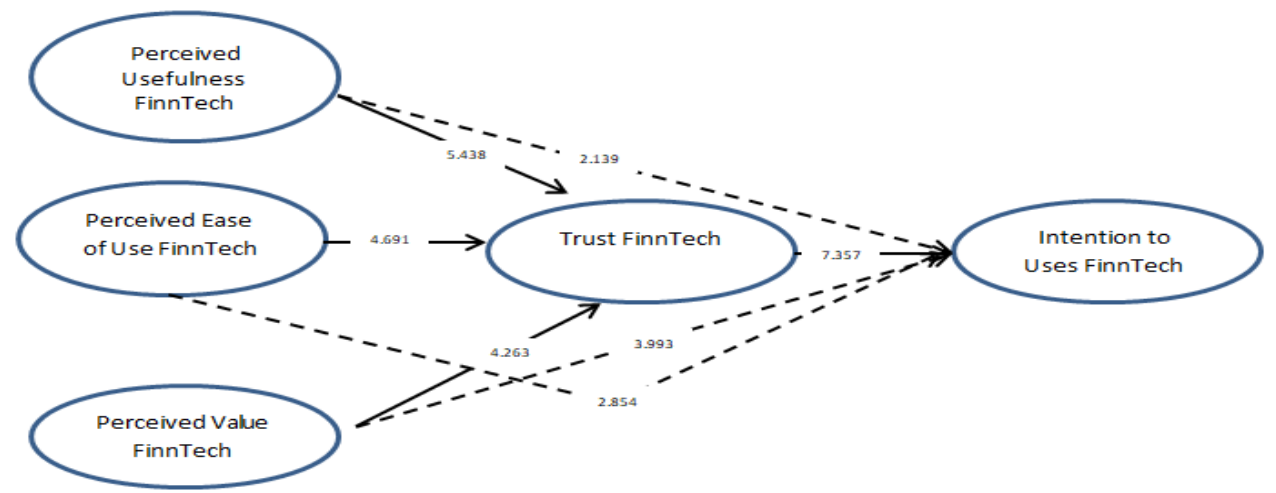

Source: From Data Processing FinnTech m-Banking BPD (2020).

Based on the testing results above, the research variables indicate that perceived usefulness has the most significant influence on the variable trust as the intervening variable with the figure of 5.438 compare to variable of perceived ease of use with the figure of 4.691 and the variable of perceived value with the figure of 4.263. The direct effect of perceived value contribute the highest influence towards intention to use with the figure of 3.993 compare to the direct effect of variable perceived ease of use with the figure of 2.139 and perceived usefulness with the figure of 2.854. The variable trust as the intervening variable also has a positive effect on intention to use with the figure of 7.357 which means the intervening variable has a significant effect on the intention to use the mobile banking application.

\subsection{Discussion}

The influence of percived usefulness towards trust (FinnTech m-Banking BPD): Based on the testing results, the perceived usefulness has a positive and significant influence towards intention to use. The t-statistic value is larger than the t-table 1.96 and original sample is positive which means that the customer of BPD Mobile banking need the trustworthiness of the application even the application offered perceived usefulness on the mobile banking application.

\section{The influence of perceived ease of use towards trust (FinnTech m-Banking BPD):}

Based on the testing results, the perceived ease of use has a positive and significant influence towards intention to use. The t-statistic value is larger than the t-table 1.96 and original sample is positive which means that the customer of BPD Mobile banking need the trustworthiness of the application even the application offered perceived ease of use on the mobile banking application.

The influence of perceived value towards trust (FinnTech m-Banking BPD):

Based on the testing results, the trust has a positive and significant influence towards intention to use. The t-statistic value is larger than the t-table 1,96 and original 
sample is positive which means that the customer of BPD Mobile banking need the trustworthiness of the application even the application offered perceived value on the mobile banking application.

\section{The influence of perceived ease of use towards intention to use (FinnTech $m$ -} Banking BPD):

Based on the testing results, the perceived ease of use has a positive and significant influence towards decision to use. The t-statistic value is larger than the t-table 1.96 and original sample is positive which means that the customers of BPD Mobile banking has the intention to use based on the perceived ease of use offered by BPD Mobile banking application.

\section{The influence of perceived usefulness towards intention to use (FinnTech m- Banking BPD):}

Based on the testing results, the perceived usefulness has a positive and significant influence towards decision to use. The t-statistic value is larger than the t-table 1.96 and original sample is positive which means that the customers of BPD Mobile banking has the intention to use based on the perceived usefulness offered by BPD Mobile banking application.

\section{The influence of perceived value towards Intention to use (FinnTech m-Banking BPD):}

Based on the testing results, the trust has a positive and significant influence towards decision to use. The t-statistic value is larger than the t-table 1.96 and original sample is positive which means that the customers of BPD Mobile banking has the intention to use based on the perceived value offered by BPD Mobile banking application.

\section{The influence of trust towards intention to use (FinnTech m-Banking BPD):}

Based on the testing results, the intention to use has a positive and significant influence towards decision to use. The t-statistics value is larger than the t-table 1.96 and original sample is positive which means that the customers of BPD Mobile banking has the intention to use based on the trustworthiness of BPD Mobile banking application

\section{Conclusion, Implications and Limitations}

\subsection{Conclusion}

Perceived usefulness has the highest effect on intention to use compared to perceived ease of use and perceived value variables. Perceived value has the highest direct influence on intention to use compared to perceived ease of use and perceived usefulness variables. The objectives of this research is to find out how does the BPD Mobile banking application attract the customers to chooses their application 
compare to the rest of the competitors. This research has constructed five researched variables to find out the intention to use of BPD Mobile banking application.

The Mobile banking application is easy to use for banking activities at BPD banks. The BPD Mobile banking application is a mobile banking application because it is considered useful and does not need to come to the bank. The BPD Mobile banking application has the perceived value of the application. Trust in the BPD Mobile banking application before choosing to use the application. However, it was found that the BPD Mobile banking application has several shortcomings, namely frequent lost connections, limited banking services and imperfect systems..

\subsection{Implications}

The study has generated several theoretical and practical implications such as:

1. Perceived usability of FinnTech, perceived ease of use of FinnTech, and perceived value of FinnTech have a positive and significant effect on the trust of FinnTech worthiness of the mobile banking application. The results show that strategic business concepts can help participate and contribute to a competitive advantage over competitors.

2. Perceived usefulness of FinnTech, perceived ease of use of FinnTech and perceived value of FinnTech have a positive and significant effect on intention to use FinnTech the mobile banking application. Research shows that strategic business concepts can help customers to choose and decide which application they will choose.

3. Perceived usefulness of FinnTech, perceived ease of use of FinnTech and perceived value of FinnTech have a positive and significant effect on intention to use FinnTech in relation to trust FinnTech in the BPD Mobile banking application as an intervening variable.

\subsection{Limitations}

The research analysis is only on customers who choose BPD Mobile banking as a mobile banking application. This research is also limited by the variables of perceived usefulness, perceived ease of use and perceived value of the intention to use digital payment applications, it may be necessary to carry out further analysis with a larger sample with a comparison of different banks. Further research can be carried out on the advantages and disadvantages of the mobile banking application as well as the security of the system by adding a wider range of variables.

\section{References:}

Aldiabat, K., Al-Gasaymeh, A.,Ameer Sardar Kwekha, R. 2019. The Effect of Mobile Banking Application on Customer Interaction in the Jordanian Banking Industry. International Journal of Interactive Mobile Technologies, 13(2), 37-49. 
Al-Dmour, R., Dawood, E.A.H., Al-Dmour, H., Masa'deh, R.E. 2020. The effect of customer lifestyle patterns on the use of mobile banking applications in Jordan. International Journal of Electronic Marketing and Retailing, 11(3), 239-258.

Asosiasi Penyelenggara Jasa Internet Indonesia (APJII). 2017. Pertumbuhan Pengguna Internet. Retrieved from apjii.or.id: https://apjii.or.id/survei2017s/kirimlink.

Bank BPD. 2020. Mobile Banking. Available online: https://www.bpdbali.co.id/page/read/71 Retrieved.

Del Mundo, C.F.S. 2019. How countries seek to strengthen anti-money laundering laws in response to the Panama papers, and the ethical implications of incentivizing whistleblowers. Nw. J. Int'l L. \& Bus., 40, 87.

Davis, F.D., Davis, F. 1989. Perceived Usefulness, Perceived Ease of Use, and User Acceptance of Information Technology. European Journal of Business and Management Research, 4(5), 1-24.

Dong, X., Hu, Y., Yin, W., Kuo, E. 2019. Zhongguancun Cases. In Zhongguancun Model: Driving the Dual Engines of Science and Technology and Capital, 135-260. Springer, Singapore.

Gitahi, O.K., Misango, S. 2020. The Influence of Customer Retention Strategies on the Organization Performance of Commercial Banks in Thika Town. European Journal of Business and Strategic Management, 5(2), 11-29.

Harelimana, J.B. 2017. Impact of Mobile Banking on Financial Performance of Unguta Microfinance Bank Ltd., Rwanda. Global Journal of Management and Business Research and Finance, 17(4), 1-13.

Johannes, V.D., Indarini, I., Margaretha, S. 2018. Usability, Customer Satisfaction, Service, and Trust towards Mobile Banking User Loyalty. Advances in Social Science, Education and Humanities Research, 186(15), 1-4.

Kotler, P., Armstrong, G. 2016. Principles of Marketing, Sixteenth Edition. Pearson Education Limited, England.

Kotler, P., Keller, K.L. 2016. Marketing Management, Fifteenth Edition. Pearson Education Limited, England.

Khosa, T. 2019. The effects of mobile money transfer services on traditional banking services offered by banks: case study of BancABC (Doctoral dissertation, BUSE).

Lutfi, L., Kristijadi, E., Silvy, M. 2020. Simultaneous adjustment of bank capital and risk: Evidence from the Indonesian commercial banks. Accounting, 6(5), 637-648.

Maseke, B.F. 2018. The Impact of Mobile Banking on Customer Satisfaction: Commercial Banks of Namibia. Journal of Internet Banking and Commerce, 23(2), 1-18.

Ouma, S.O., Ndede, F.W. 2020. Adoption of Digital Banking Technology and Financial Performance of Commercial Banks in Kenya. International Journal of Current Aspects in Finance, Banking and Accounting, 2(1), 42-50.

Puriwat, W., Tripopsakul, S. 2017. Mobile Banking Adoption in Thailand: An Integration of Technology Acceptance Model and Mobile Service Quality. European Research Studies Journal, Vol. XX, Issue 4A, 200-210.

Putra, I., Sunarsih, N., Novitasari, L., Setini, M. 2020. Exploring the relationship between social capital, innovation capability and innovation during the coronavirus pandemic. Uncertain Supply Chain Management, 8(4), 857-864.

Prasetyaningsih, E., Astini, R. 2016. Pengaruh Citra Merek dan Gaya Hidup terhadap Keputusan Pembelian Produk Tas Branded Tiruan pada Wanita Karir Di Bali. Jurnal Ilmiah Manajemen dan Bisnis, Vol. 2, No. 2, 1-14. 
Ravichandran, D., Harshani, Madana Hiti Bandaralage, A. 2016. Factors Influencing Mobile Banking Adoption in Kurunegala District. Journal of Information Systems and Information Technology, Vol. 1, No. 1, 24-32.

Sapta, I.K.S., Landra, N., Supartha, I.W.G., Asih, D., Setini, M. 2020. Public Health welfare in Digital-based Resources Transformation from Social Capital and Information Sharing: Creative Industries from Village. Systematic Reviews in Pharmacy, 11(6), 688-696.

Setini, M., Yasa, N.N.K., Gede Supartha, I.W., Ketut Giantari, I., Rajiani, I. 2020. The Pass way of Women Entrepreneurship: Starting from Social Capital with Open Innovation, through to Knowledge Sharing and Innovative Performance. Journal of Open Innovation: Technology, Market, and Complexity, 6(2), 25.

Shiau, W.L., Yuan, Y., Pu, X., Ray, S., Chen, C.C. 2020. Understanding fintech continuance: perspectives from self-efficacy and ECT-IS theories. Industrial Management \& Data Systems.

Tam, C., Oliveira, T. 2017. Literature Review of Mobile Banking and Individual Performance. International Journal of Bank Marketing, 35(7), 1042-1065.

Thalassinos, I.E., Thalassinos, E.Y. 2018. Financial Crises and e-Commerce: How Are They Related? Available at SSRN: https://ssrn.com/abstract=3330169.

Top Brand Award. 2019. M-Banking Top Brand Award. Retrieved from topbrandaward.com: https://www.topbrand-award.com/top-brand-index/.

Vuković, M., Martinov, D., Mazić, Ž. 2020. Analysis of Suplly and Demand for Electronic Banking Services in the South Bačka Region. Economic Themes, 58(1).

Wang, Y., Gu, J., Wang, S., Wang, J. 2019. Understanding consumers' willingness to use ride-sharing services: The roles of perceived value and perceived risk. Transportation Research Part C: Emerging Technologies, 105, 504-519.

Zheng, Y., Zhang, Y., Qian, K., Zhang, G., Liu, Y., Wu, C., Yang, Z. 2019. Zero-effort crossdomain gesture recognition with Wi-Fi. In Proceedings of the 17th Annual International Conference on Mobile Systems, Applications, and Services, 313-325. 